\title{
Obtaining Triploid Hybrids by Means of Open Pollinations and Controlled Crosses Involving Diploids Parental
}

\author{
Reisane Teles Santiago ${ }^{1}$, Antônio da Silva Souza ${ }^{2}$, Carlos Alberto da Silva Ledo², \\ Lucas Aragão da Hora Almeida ${ }^{3}$, Karen Cristina Fialho dos Santos ${ }^{2}$, Abelmon da Silva Gesteira ${ }^{2}$ \\ $\&$ Walter dos Santos Soares Filho ${ }^{2}$ \\ ${ }^{1}$ Center of Agrarian, Environmental and Biological Sciences, Federal University of Recôncavo of Bahia, Cruz \\ das Almas, Bahia, Brazil \\ ${ }^{2}$ Embrapa Cassava and Fruits, Cruz das Almas, Bahia, Brazil \\ ${ }^{3}$ State University of Santa Cruz, Ilhéus, Bahia, Brazil \\ Correspondence: Walter dos Santos Soares Filho, Embrapa Cassava and Fruits, Cruz das Almas, Bahia, Brazil. \\ Tel: 55-3312-8046. E-mail: walter.soares@embrapa.br
}

Received: January 11, 2019

Accepted: February 14, 2019 Online Published: April 15, 2019

doi:10.5539/jas.v11n5p195

URL: https://doi.org/10.5539/jas.v11n5p195

\begin{abstract}
The creation of triploid hybrids is an important genetic improvement strategy for the development of new commercial citrus scion varieties. The objective of this work was to quantify the frequency of triploids obtained from natural and controlled crosses of different mandarin varieties under varying environmental conditions in the state of Bahia. The experiments were conducted in the municipalities of Cruz das Almas (Recôncavo Baiano region) and Mucugê (Chapada Diamantina region). The first experiment was based on fruits from open pollinations of the varieties 'Page', 'Ortanique', 'Ellendale', 'Clemenules', 'Swatow', 'Piemonte', 'Fortune', 'South Africa', 'Montenegrina', 'Kincy', 'Span Americana', 'Fremont, 'Nova', 'Dancy' and 'Murcott', and the second involved fruits from controlled crosses of female parents 'Nova', 'Fortune' and 'Ortanique' and male parents 'Page', 'Montenegrina', 'Swatow', 'Fremont' and 'Kincy'. The seeds selected were inoculated in test tubes containing approximately $10 \mathrm{~mL}$ of Woody Plant Medium (WPM). When the plants reached circa 60 days of age, leaf samples were removed for quantification of the DNA by the flow cytometry technique. In Mucugê, three triploids were identified from open pollinations, 'Clemenules' (1) and 'Ortanique' (2), while in Cruz das Almas, no triploids were obtained. In the controlled crosses, triploids were only obtained in Mucugê: 'Ortanique' $\times$ 'Montenegrina' (4), 'Ortanique' $\times$ 'Kincy' (1) and 'Ortanique' $\times$ 'Swatow' (2). Based on the data, it is suggested that the environmental conditions of Mucugê favored the formation of triploids.
\end{abstract}

Keywords: Citrus spp., in vitro culture, hybridization, genetic improvement

\section{Introduction}

Citrus are among the most important group of fruit trees in Brazil, due to the nutritive value of the fruits and the socioeconomic role they play in the export (Knudsen, Almeida, Langer, Abreu, \& Halberg, 2011). In this aspect, the expansion of the genetic base of Brazilian orchards, especially related to the varieties used for scion and rootstocks, including those with capacity to adapt to abiotic stresses, tends to contribute significantly to the achievement of economically superior incomes in the country (Syvertsen \& Sanchez, 2014).

Although citrus presents great importance in the economy, Brazil has little expressive participation in the world exports of fresh orange and mandarin. In addition to phytosanitary issues, one of the reasons for the low Brazilian participation in this market is the lack of cultivars that meet the minimum quality requirements demanded by the external market of fresh fruit, being one of the main ones, the absence of seeds in the fruits (Latado, Carvalho, \& Machado, 2007).

One of the strategies used to obtain seedless fruits is the cultivation of triploid genotypes, such as the acid lime tree 'Tahiti' [Citrus latifolia (Yu. Tanaka)], which has high commercial value and is highly productive (Silva, Bezerra, Bassan, Avilés, \& Arthur, 2016). Triploid hybrids in citrus can be obtained from crosses of diploid (2×) parents with tetraploids $(4 \times)$, hexaploids $(6 \times)$ with tetraploids $(4 \times)$ and diploids $(2 \times)$ with diploids $(2 \times)$ or open pollinated, in the case of $2 \times$ with $2 \times$, the triploid embryos originate from the fertilization of non-reduced female 
gametes (diploids), with reduced male gametes (haploids), being the natural frequency of obtaining triploides very low (close to 5\%), varying according to the maternal genotype (Esen \& Soost, 1971, 1973a).

Parthenocarpy is a fundamental peculiarity for the production of seedless fruits, and is a characteristic that is present in citrus germplasm (Aleza, Cuenca, Juárez, Pina, \& Navarro, 2010a). Thus, the creation of triploid hybrids is an important genetic improvement strategy for the development of new commercial scion varieties (Ollitrault, Dambier, Luro, \& Froelicher, 2008).

The objective of this study is to quantify the frequency of triploids obtained from natural crosses (open pollinations) and controlled crosses of different mandarin varieties in varying environmental conditions in the state of Bahia, in Brazil.

\section{Materials and Methods}

\subsection{Agroclimatic Conditions of the Study Area}

The experiments were conducted in two municipalities in the state of Bahia in Brazil. The first was Cruz das Almas, located in the Recôncavo Baiano region, with geographic coordinates $12^{\circ} 40^{\prime} 19^{\prime \prime}$ southem latitude and $39^{\circ} 06^{\prime} 23^{\prime \prime}$ eastem longitude, at an elevation of $226 \mathrm{~m}$. The climate is hot and tropical with an average annual rainfall of $1170 \mathrm{~mm}$, varying from $900 \mathrm{~mm}$ to $1300 \mathrm{~mm}$, with the rainy season lasting from March to August and the dry season was from September to February. The average annual temperature is $24.5{ }^{\circ} \mathrm{C}$ and the relative humidity is $80 \%$.

The second municipality was Mucugê, in the Chapada Diamantina region, with geographic coordinates $13^{\circ} 00^{\prime} 19^{\prime \prime}$ southem latitude, $41^{\circ} 22^{\prime} 15^{\prime \prime}$ westem longitude and at an altitude of $983 \mathrm{~m}$. The climate is characterized as semi-humid, with the rainy season lasting from October to March and the dry season from April to September. The average annual rainfall is about $1100 \mathrm{~mm}$, with an average of $600 \mathrm{~mm}$ in the dry season and $1500 \mathrm{~mm}$ in the wet season, while the average yearly temperature is $20^{\circ} \mathrm{C}$.

\subsection{Experimental Design}

Two experiments were conducted, one involving fruits collected from open pollinated trees of two farms and the second one involving fruits collected from controlled pollinations.

\subsection{Materials}

\subsubsection{Source of Planting Material}

The planting material (seed) used for raising seedlings was collected from fruits raised in two experimental locations. The fruits from the open pollinations were collected in different months of the year 2015, the fruits of all the varieties were collected when they were ripe (with the coloration of the yellowish bark), the same collection criteria were used, both for fruits from open pollinations and from controlled crosses. The experiment was conducted in three locations: at the Citrus Active Germplasm Bank of the Embrapa Cassava and Fruits, located at the municipality of Cruz das Almas; and in two farms: (Alpercata farm and Lavoura and Pecuária Igarashi Ltda farm) both located in the municipality of Mucugê.

The sample collections were done in April, May and June 2015. A sample of thirty fruits were collected, from each of fifteen varieties open pollinated: 'Ortanique' tangor [Citrus reticulata Blanco $\times$ C. sinensis (L.) Osbeck]; 'Clemenules' mandarin (C. clementina hort. ex Tanaka); 'Montenegrina' mandarin (C. deliciosa Ten.); 'Nova' tangelo ['Clementina' mandarin $(C$. clementina $) \times$ 'Orlando' tangelo (C. paradisi Macfad.) $\times C$. tangerina hort. ex Tanaka]; 'Piemonte' tangelo ['Clemenules' mandarin $\times$ 'Murcott' tangor $(C$. reticulata $\times$ C. sinensis]; 'Page' tangelo ['Clementina' mandarin $\times$ 'Minneola' tangelo $(C$. paradisi $\times C$. tangerina]; 'Dancy' mandarin $(C$. tangerina); 'Fremont' mandarin ('Clementina' mandarin $\times$ 'Ponkan' mandarin $C$. reticulata); 'Ellendale' tangor $(C$. reticulata $\times C$. sinensis $)$; 'Fortune' mandarin $(C$. clementina $\times C$. tangerina $)$; 'Span Americana' mandarin $(C$. reticulata); 'Murcott' tangor $(C$. reticulata $\times C$. sinensis); 'Kincy' mandarin ['King' mandarin ( $C$. nobilis Lour.) $\times$ 'Dancy' mandarin]; 'Swatow' mandarin (C. reticulata); and 'South Africa' mandarin (C. reticulata).

The controlled pollinations were performed at the Citrus Active Germplasm Bank of the Embrapa Cassava and Fruits, located at the municipality of Cruz das Almas; and in two farms: (Alpercata farm and Lavoura and Pecuária Igarashi Ltda farm) both located in the municipality of Mucugê. The controlled crosses were carried out in the month of September of the year of 2015, involving the varieties Nova, Fortune and Ortanique as female parental, and the male parents 'Page', 'Montenegrina', 'Swatow', 'Fremont' and 'Kincy'.

The number of controlled pollinations varied according to the availability of flowers at the time of their realization. They were carried out in the period of greatest solar intensity and temperature, on dry days, between 10:00 a.m. and 4:00 p.m., to facilitate release and use of the pollen. 
The pollen collected from recently opened male parents was used to pollinate the female parent flowers, which had been emasculated before anthesis. The emasculation was performed in the balloon stage (close to floral opening), by carefully eliminating the petals and anthers with tweezers and scalpel, avoiding contact with the stigma. The pollination was performed immediately after emasculation, while the stigma was receptive (moist).

The fruits were collected between four and five months after the pollinations. Those from both the natural pollinations and controlled crosses were taken to the Tissue Culture Laboratory. The seeds were removed by an incomplete transversal cut in each fruit, to assure integrity the same (Figures 1A and 1B). After extraction, the seeds were washed with neutral detergent and tap water (Figure 1C), counted per fruit and classified according to the development stage and size, as normal (seeds with well-formed tegument), underdeveloped (seeds with wrinkled tegument) and small (seeds with 1/6 to 1/3 of normal size), as shown in Figure 1D.

Seeds were selected with priority that were 3 to 6 times smaller than the seeds containing diploid embryos, since these have strong potential to produce triploid individuals (Aleza, Juárez, Cuenca, Ollitrault, \& Navarro, 2010b).

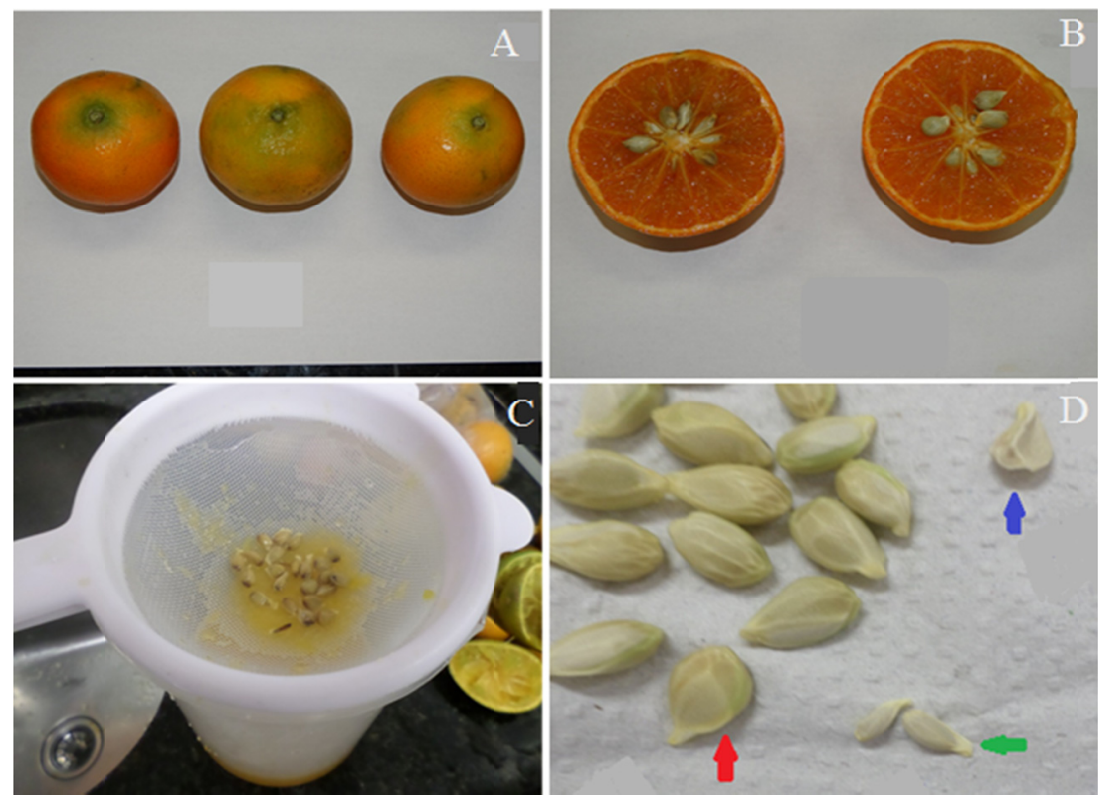

Figure 1. A: Fruits of the Page variety; B: fruits cut to remove the seeds; C: Seeds were washed with neutral detergent; D: Seeds classified as having normal size, indicated by the red arrow, underdeveloped, indicated by the blue arrow, and small, indicated by the green arrow

The tegument of all small seeds, undeveloped and 20 normal seeds has been removed, being that the number of small and underdeveloped seeds inoculated varied according to the quantity of seeds available. The seeds were disinfested under aseptic conditions in a laminar flow cabinet by immersion in $70 \%$ ethanol for 5 minutes, followed by a $0.5 \%$ sodium hypochlorite solution containing two droplets of Tween $20^{\circledR}$ for 20 minutes and three washings in autoclaved distilled water. The disinfested seeds were then inoculated in test tubes containing approximately $10 \mathrm{~mL}$ of Woody Plant Medium-WPM (Lloyd \& McCown, 1980) and kept in a growth room at temperature of $27 \pm 1{ }^{\circ} \mathrm{C}$, with photon flux density of $30 \mu \mathrm{mol} \mathrm{m}^{-2} \mathrm{~s}^{-1}$ and $16: 8$ hour photoperiod.

\subsubsection{Flow Cytometry Analyses}

When the plants reached 60 days of age, leaf samples were removed for DNA quantification by flow cytometry according to the method described by Dolezel, Greilhuber, and Suda (2007), with the modification that tests were performed with the species Crotalaria breviflora DC for comparison with a citrus standard consisting of 'Sunki Tropical' mandarin (Citrus sunki (Hayata) hort. ex Tanaka), to define the DNA content. The analysis was performed using small citrus leaf fragments $(2 \mathrm{C}=0.70 \mathrm{pg}$ of DNA) for comparison with the content of Crotalaria breviflora $(2 \mathrm{C}=2.02 \mathrm{pg}$ of $\mathrm{DNA})$. The samples were macerated in Petri dishes over ice in the presence of $1 \mathrm{~mL}$ of LB01 nuclear isolation buffer (Dolezel \& Bartos, 2005), followed by addition of $0.20 \mu \mathrm{L}$ of propidium iodide to stain the DNA. The DNA content (pg) of the unknown samples was determined according to Dolezel et al. (2007) with the formula: 


$$
\text { Sample 2C value }\left(\text { DNA pg) }=\frac{\text { Sample mean peak position } \times \text { Reference } 2 \mathrm{C} \text { value }}{\text { Reference } 2 \mathrm{C} \text { mean peak position }}\right.
$$

Flow cytometry analyses generate histograms that allow identifying the ploidy level of the individuals evaluated. Figures 2 and 3 contain the histograms generated by the flow cytometry method, to illustrate how the triploids were identified.

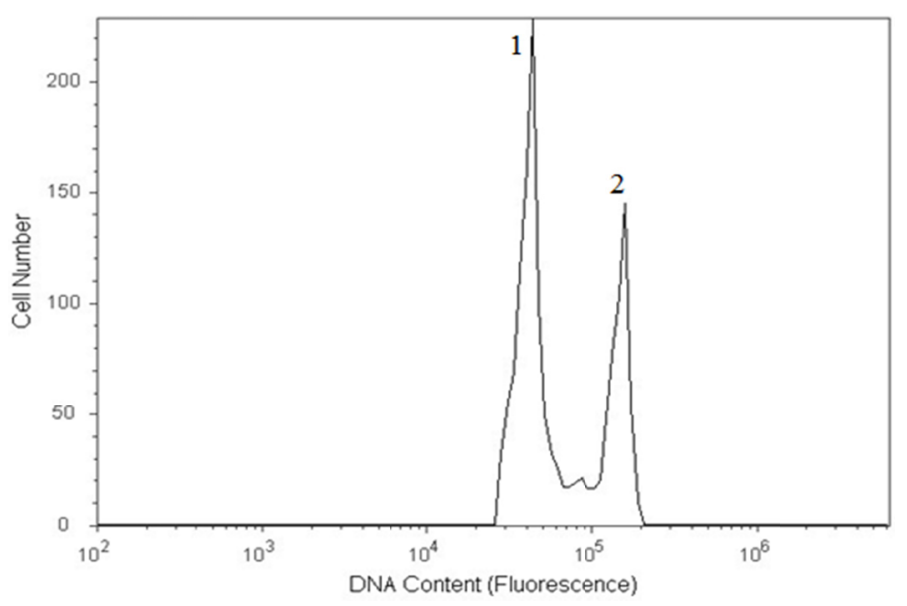

Figure 2. Histogram obtained by flow cytometry analysis of a diploid leaf sample of 'Cravo' mandarin (Citrus reticulata Blanco) (peak 1) and a sample of the diploid control, Crotalaria breviflora DC. (peak 2)

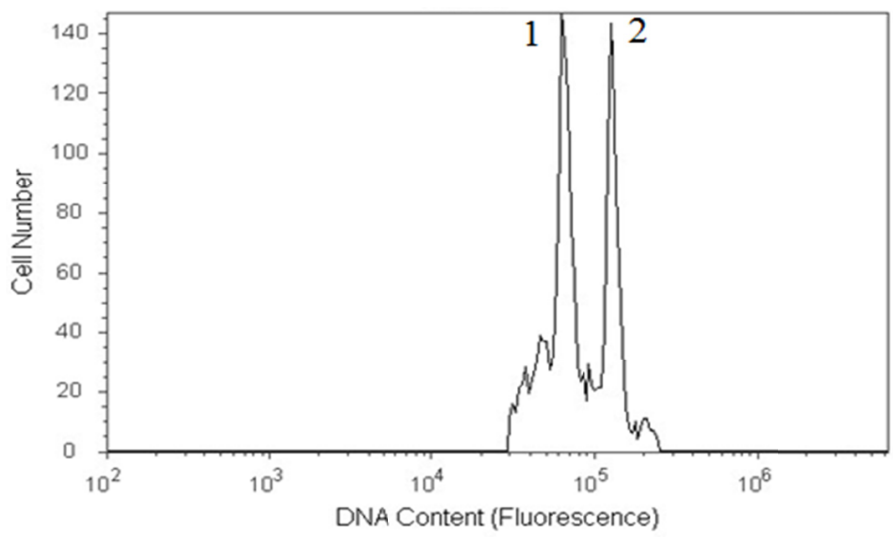

Figure 3. Histogram obtained by flow cytometry analysis of a leaf sample of a triploid 'Fortune' mandarin (Citrus clementina hort. ex Tanaka $\times$ Citrus tangerina hort. ex Tanaka) (peak 1) and a diploid control sample, Crotalaria breviflora DC (peak 2)

\section{Results}

\subsection{Ploidy of the Citrus Plants Obtained From Open Pollinations, Measured by Flow Cytometry}

The data related to the 15 mandarin varieties collected in Cruz das Almas and Mucugê, in April, May and June 2015, are reported in Table 1. In Mucugê, the frequency of obtaining triploids among the varieties was of $100 \%$ ('Ortanique' and 'Clemenules'). The frequency variations occurred in function of the percentage of germinated seeds, type of seed, environment and genotype. There was a low germinated seed rate due to losses caused by contamination. All the undeveloped and small seeds found in the fruits were placed to germinate. However, a low number of plants was obtained, because there was a lot of loss due to the contamination of seeds by endogenous bacteria and fungi, making it difficult to analyze a larger number of samples. 
Table 1. Frequency of obtaining triploid hybrids with 15 mandarin varieties, in function of genotype, seed type (normal seed-N and underdeveloped seed-UD) and environment (Cruz das Almas-CZA and Mucugê-MCG). Fruits collected in April, May and June 2015

\begin{tabular}{|c|c|c|c|c|c|c|c|}
\hline \multirow{2}{*}{ Seed } & \multirow{2}{*}{ Variety $^{1}$} & \multicolumn{2}{|c|}{ Germination (\%) } & \multicolumn{2}{|c|}{ Plants obtained } & \multicolumn{2}{|c|}{ Triploids (\%) } \\
\hline & & CZA & MCG & CZA & MCG & CZA & MCG \\
\hline \multirow{15}{*}{$\mathrm{N}$} & South Africa & 20 & 40 & 1 & 2 & 0 & 0 \\
\hline & Clemenules & 40 & 20 & 2 & 1 & 0 & 0 \\
\hline & Dancy & 40 & 40 & 2 & 2 & 0 & 0 \\
\hline & Ellendale & 0 & 0 & 0 & 0 & 0 & 0 \\
\hline & Fortune & 0 & 80 & 0 & 4 & 0 & 0 \\
\hline & Fremont & 20 & 40 & 1 & 2 & 0 & 0 \\
\hline & Kincy & 100 & 20 & 5 & 1 & 0 & 0 \\
\hline & Montenegrina & 0 & 0 & 0 & 0 & 0 & 0 \\
\hline & Murcott & 0 & 0 & 0 & 0 & 0 & 0 \\
\hline & Nova & 100 & 40 & 5 & 2 & 0 & 0 \\
\hline & Ortanique & 0 & 100 & 0 & 5 & 0 & 0 \\
\hline & Page & 0 & 0 & 0 & 0 & 0 & 0 \\
\hline & Piemonte & 0 & 0 & 0 & 0 & 0 & 0 \\
\hline & Span Americana & 40 & 20 & 2 & 1 & 0 & 0 \\
\hline & Swatow & 0 & 0 & 0 & 0 & 0 & 0 \\
\hline \multirow{15}{*}{ UD } & South Africa & 0 & 20 & 0 & 1 & 0 & 0 \\
\hline & Clemenules & 0 & 20 & 0 & 1 & 0 & $1(100 \%)$ \\
\hline & Dancy & 20 & 40 & 1 & 2 & 0 & 0 \\
\hline & Ellendale & 20 & 0 & 1 & 0 & 0 & 0 \\
\hline & Fortune & 0 & 0 & 0 & 0 & 0 & 0 \\
\hline & Fremont & 0 & 0 & 0 & 0 & 0 & 0 \\
\hline & Kincy & 0 & 0 & 0 & 0 & 0 & 0 \\
\hline & Montenegrina & 0 & 20 & 0 & 1 & 0 & 0 \\
\hline & Murcott & 0 & 60 & 0 & 3 & 0 & 0 \\
\hline & Nova & 40 & 80 & 2 & 4 & 0 & 0 \\
\hline & Ortanique & 0 & 40 & 0 & 2 & 0 & $2(100 \%)$ \\
\hline & Page & 0 & 20 & 0 & 1 & 0 & 0 \\
\hline & Piemonte & 20 & 0 & 1 & 0 & 0 & 0 \\
\hline & Span Americana & 0 & 40 & 0 & 2 & 0 & 0 \\
\hline & Swatow & 0 & 0 & 0 & 0 & 0 & 0 \\
\hline
\end{tabular}

$\overline{\text { Note. }}{ }^{1}$ Tangor 'Ortanique' [Citrus reticulata Blanco $\times$ C. sinensis (L.) Osbeck]; 'Clemenules' mandarin $(C$. clementina hort. ex Tanaka); 'Montenegrina' mandarin ( $C$. deliciosa Ten.); 'Nova" tangelo ['Clementina' mandarin $(C$. clementina $) \times$ 'Orlando' tangelo $(C$. paradisi Macfad. $) \times C$. tangerina hort. ex Tanaka]; 'Piemonte' tangelo ['Clemenules' mandarin $\times$ 'Murcott' tangor $(C$. reticulata $\times C$. sinensis]; 'Page' tangelo ['Clementina' mandarin $\times$ 'Minneola' tangelo $(C$. paradisi $\times C$. tangerina $]$; 'Dancy' mandarin $(C$. tangerina $)$; 'Fremont' mandarin ('Clementina' mandarin $\times$ 'Ponkan' mandarin C. reticulata); 'Ellendale' tangor $(C$. reticulata $\times C$. sinensis); 'Fortune' mandarin (C. clementina $\times$ C. tangerina); 'Span Americana' mandarin (C. reticulata); 'Murcott' tangor (C. reticulata $\times$ C. sinensis); 'Kincy' mandarin ['King' tangerine (C. nobilis Lour.) $\times$ 'Dancy' mandarin]; 'Swatow' mandarin (C. reticulata) e 'South Africa' madarin (C. reticulata).

With respect to the environmental effect on the formation of seeds with potential to generate triploid plants, the conditions in Mucugê were favorable. Three triploids were identified from this location, one of the 'Clemenules' variety and two 'Ortanique' (Table 1). For the locality of Cruz das Almas, triploids were not obtained.

Though the environment in Mucuge favored the formation of triploid in comparation to Cruz das Almas, mention should be made of the low seed germination rate in both environments and, consequently, the small number of plants obtained. But, all the plants produced by in vitro culture, regardless of the seed type and local, were evaluated by flow cytometry.

\subsection{Ploidy of Citrus Plants Obtained From Controlled Crosses, Measured by Flow Cytometry}

We performed 197 pollinations in Cruz das Almas (Table 2): 'Ortanique' $\times$ 'Kincy' (5); 'Ortanique' $\times$ 'Fremont' (19); 'Nova' × 'Kincy' (43); 'Nova' $\times$ 'Page' (71); 'Fortune' $\times$ 'Kincy' (10); and 'Fortune' $\times$ 'Page' (49). The fruit-setting rates varied from $4 \%$ ('Nova' $\times$ 'Page') to $40 \%$ ('Ortanique' $\times$ 'Kincy'). 
Table 2. Controlled crosses carried out in Cruz das Almas. Number of flowers pollinated (NP), number of fruits obtained after pollination (NF) and fruit-setting rate (SR)

\begin{tabular}{llll}
\hline Crosses $^{1}$ & NP & NF & SR (\%) \\
\hline 'Ortanique' × 'Kincy' & 5 & 2 & 40 \\
'Ortanique' × 'Fremont' & 19 & - & - \\
'Nova' × 'Kincy' & 43 & 15 & 35 \\
'Nova' × 'Page' & 71 & 3 & 4 \\
'Fortune' × 'Kincy' & 10 & - & - \\
'Fortune' × 'Page' & 49 & - & - \\
Total & 197 & 20 & \\
\hline
\end{tabular}

Note. ${ }^{1}$ Tangor 'Ortanique' [Citrus reticulata Blanco $\times$ C. sinensis (L.) Osbeck]; 'Kincy' mandarin ['King' mandarin (C. nobilis Lour.) $\times$ 'Dancy' mandarin (C. tangerina hort. ex Tanaka)]; 'Nova' tangelo ['Clementina' mandarin $(C$. clementina hort. ex Tanaka) $\times$ 'Orlando' tangelo $(C$. paradisi Macfad. $) \times C$. tangerina $]$; 'Page' tangelo ['Clementina' mandarin $\times$ 'Minneola' tangelo $(C$. paradisi $\times C$. tangerina $)$ ]; 'Fremont' mandarin ['Clementina' mandarin $\times$ 'Ponkan' mandarin $(C$. reticulata) $]$; 'Fortune' mandarin ('Clementina' mandarin $\times$ 'Dancy' mandarin).

In Mucugê we carried out 734 pollinations (Table 3): 'Ortanique' $\times$ 'Kincy' (66); 'Ortanique' $\times$ 'Montenegrina' (86); 'Ortanique' $\times$ 'Page' (67); 'Ortanique' $\times$ 'Fremont' (17); 'Ortanique' $\times$ 'Swatow' (61); 'Nova' $\times$ 'Kincy' (28); 'Nova' $\times$ 'Montenegrina' (75); 'Nova' $\times$ 'Page' (81); 'Nova' $\times$ 'Fremont' (52); 'Nova' $\times$ 'Swatow' (122); 'Fortune' $\times$ 'Kincy' (16); 'Fortune' $\times$ 'Montenegrina' (11); 'Fortune' $\times$ 'Page' (22); 'Fortune' $\times$ 'Fremont' (12); and 'Fortune' $\times$ 'Swatow' (18). In this case, the fruit-setting rates varied between $7 \%$ in the 'Nova' $\times$ 'Page' cross and $39 \%$ for 'Ortanique' $\times$ 'Swatow'.

Table 3. Controlled crosses in Mucugê. Number of flowers pollinated (NP), number of fruits obtained after pollination (NF) and fruit-setting rate (SR)

\begin{tabular}{|c|c|c|c|}
\hline Crosses $^{1}$ & NP & NF & SR (\%) \\
\hline 'Ortanique' $\times$ 'Kincy' & 66 & 15 & 23 \\
\hline 'Ortanique' $\times$ 'Montenegrina' & 86 & 33 & 38 \\
\hline 'Ortanique' $\times$ 'Page' & 67 & 22 & 33 \\
\hline 'Ortanique' $\times$ 'Fremont' & 17 & 4 & 24 \\
\hline 'Ortanique' $\times$ 'Swatow' & 61 & 24 & 39 \\
\hline 'Nova' $\times$ 'Kincy' & 28 & 6 & 21 \\
\hline 'Nova'x 'Montenegrina' & 75 & 18 & 24 \\
\hline 'Nova' $\times$ 'Page' & 81 & 6 & 7 \\
\hline 'Nova' $\times$ 'Fremont' & 52 & 14 & 27 \\
\hline 'Nova' × 'Swatow' & 122 & 39 & 32 \\
\hline 'Fortune' × 'Kincy' & 16 & - & - \\
\hline 'Fortune' $\times$ 'Montenegrina' & 11 & - & - \\
\hline 'Fortune' $\times$ 'Page' & 22 & - & - \\
\hline 'Fortune' $\times$ 'Fremont' & 12 & - & - \\
\hline 'Fortune' × 'Swatow' & 18 & - & - \\
\hline Total & 734 & 181 & \\
\hline
\end{tabular}

Note. ${ }^{1}$ Tangor 'Ortanique' [Citrus reticulata Blanco $\times$ C. sinensis (L.) Osbeck]; 'Kincy' mandarin ['King' mandarin (C. nobilis Lour.) $\times$ 'Dancy' mandarin (C. tangerina hort. ex Tanaka)]; 'Montenegrina' mandarin (C. deliciosa Ten.); 'Page' tangelo ['Clementina' mandarin (C. clementina hort. ex Tanaka) $\times$ 'Minneola' tangelo ( $C$. paradisi Macfad. $\times C$. tangerina $)$; ' 'Fremont' mandarin ['Clementina' mandarin $\times$ 'Ponkan' mandarin $(C$. reticulata)]; 'Nova”' tangelo ['Clementina' mandarin $\times$ 'Orlando' tangelo (C. paradisi $\times$ C. tangerina $)$ ]; 'Swatow' mandarin (C. reticulata); 'Fortune' mandarin ('Clementina' mandarin $\times$ 'Dancy' mandarin).

In the controlled crosses performed in both Cruz das Almas and Mucugê, we used as female parents the varieties 'Nova', 'Ortanique' and 'Fortune', and as male parents 'Page', 'Swatow', 'Montenegrina', 'Fremont' and 
'Kincy'. However, the fruits resulting from the crosses involving the 'Fortune' variety as female parent did not set in either location, so it was not possible to evaluate the influence of this variety on the formation of triploids.

With respect to growing location, in Mucugê seven triploids were obtained, four from 'Ortanique' $\times$ 'Montenegrina' crosses, one from 'Ortanique' $\times$ 'Kincy' and two from 'Ortanique' $\times$ 'Swatow' (Table 4; Figure 4). The triploid frequency of the crosses varied from $50 \%$ ('Ortanique' $\times$ 'Kincy') to $100 \%$ ('Ortanique' $\times$ 'Montenegrina') and ('Ortanique' $\times$ 'Swatow').

Table 4. Controlled crosses carried out in Mucugê (MCG) and Cruz das Almas (CZA). Number of plants obtained from normal seeds (NS), number of plants obtained from underdeveloped seeds (UD), number of plants obtained from small seeds (SS), percentage of plants obtained (PO\%) and percentage of triploids obtained (\%)

\begin{tabular}{|c|c|c|c|c|c|c|c|c|c|c|c|}
\hline Local & Female parent & Male parent & NS & $\mathrm{PO} \%$ & Triploids $\%$ & UD & PO\% & Triploids\% & SS & $\mathrm{PO} \%$ & Triploids\% \\
\hline \multirow{5}{*}{ MCG } & \multirow{5}{*}{ 'Ortanique' } & 'Kincy' & 3 & 8 & 0 & 0 & 0 & 0 & 2 & 4 & $1(50 \%)$ \\
\hline & & 'Montenegrina' & 9 & 9 & 0 & 0 & 0 & 0 & 4 & 50 & $4(100 \%)$ \\
\hline & & 'Page' & 10 & 17 & 0 & 0 & 0 & 0 & 0 & 0 & $0(0 \%)$ \\
\hline & & 'Swatow' & 5 & 14 & 0 & 0 & 0 & 0 & 2 & 50 & $2(100 \%)$ \\
\hline & & 'Fremont' & 2 & 10 & 0 & 1 & 20 & 0 & 0 & 0 & $0(0 \%)$ \\
\hline \multirow{4}{*}{$\mathrm{MCG}$} & \multirow{4}{*}{ 'Nova' } & 'Swatow' & 6 & 5 & 0 & 0 & 0 & 0 & 5 & 33 & $0(0 \%)$ \\
\hline & & 'Kincy' & 1 & 5 & 0 & 0 & 0 & 0 & 0 & 0 & $0(0 \%)$ \\
\hline & & 'Fremont' & 5 & 25 & 0 & 0 & 0 & 0 & 0 & 0 & $0(0 \%)$ \\
\hline & & 'Montenegrina' & 2 & 10 & 0 & 0 & 0 & 0 & 0 & 0 & $0(0 \%)$ \\
\hline \multirow{2}{*}{ CZA } & \multirow{2}{*}{ 'Nova' } & 'Kincy' & 26 & 1 & 0 & 5 & 31 & 0 & 0 & 0 & $0(0 \%)$ \\
\hline & & 'Page' & 4 & 40 & 0 & 0 & 0 & 0 & 0 & 0 & $0(0 \%)$ \\
\hline CZA & 'Ortanique' & 'Kincy' & 28 & 76 & 0 & 0 & 0 & 0 & 0 & 0 & $0(0 \%)$ \\
\hline
\end{tabular}

Note. ${ }^{1}$ Tangor 'Ortanique' [Citrus reticulata Blanco $\times$ C. sinensis (L.) Osbeck]; 'Kincy' mandarin ['King' mandarin $(C$. nobilis Lour.) $\times$ 'Dancy' mandarin (C. tangerina hort. ex Tanaka)]; 'Montenegrina' mandarin $(C$. deliciosa Ten.); 'Page' tangelo ['Clementina' mandarin $(C$. clementina hort. ex Tanaka) $\times$ 'Minneola' tangelo $(C$. paradisi Macfad. $\times$ C. tangerina) $\times$ 'Dancy' mandarin]; 'Fremont' mandarin ('Clementina' mandarin $\times$ 'Ponkan' mandarin C. reticulata); 'Swatow' mandarin (C. reticulata); 'Nova' tangelo ['Clementina' mandarin $\times$ 'Orlando' tangelo (C. paradisi $\times$ C. reticulata $)]$.

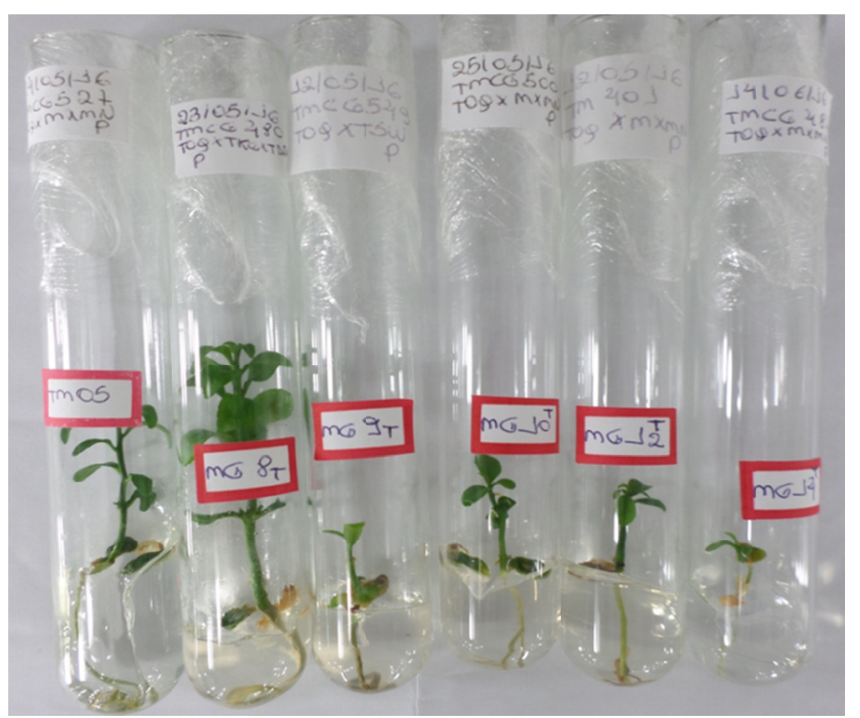

Figure 4. Triploid plants from in vitro culture of seeds from controlled crosses between the parents: 'Ortanique' tangor [Citrus reticulata Blanco $\times$ C. sinensis (L.) Osbeck] × 'Montenegrina' mandarin (C. deliciosa Ten.);

'Ortanique' mandarin $\times$ 'Swatow' mandarin (C. reticulata) 
Regarding seed type, all the triploids came from small seeds, and of the 13 plants obtained from these seeds, seven were triploids (54\% frequency). However, no triploid plants were obtained in Cruz das Almas (Table 4).

In general, although the environment conditions in Mucugê promoted a higher frequency of triploids than in Cruz das Almas, where no plants were obtained with this ploidy from the controlled crosses, the number of plants obtained in both environments was low and directly proportional to the seed germination rate, which was also low in the majority of the varieties evaluated.

\section{Discussion}

Triploid citrus hybrids can be obtained by crossing diploid parents through production of unreduced gametes by the female parent, where the frequency of these gametes depends on the genotype (Esen \& Soost, 1971; Luro, Maddy, Jacquemond, Froelicher, Morillon, Rist, \& Ollitrault, 2004). Triploid embryos are more often produced by small seeds, between $1 / 6$ and $1 / 3$ of normal size. Generally these seeds do not germinate under normal greenhouse conditions, so it is necessary to rescue and culture these embryos in vitro to attain high germination rates (Aleza et al., 2010b).

Cameron and Frost (1968) observed that the frequency of obtaining natural triploid plants in interspecific or intraspecific progenies of Citrus originating from pollinations between diploid parents was generally low (near 5\%), while according to Essen and Soost (1971), the rate varies in function of the maternal genotype. However, Aleza et al. (2010b), investigating controlled $2 \mathrm{x} \times 2 \mathrm{x}$ hybridizations involving monoembryonic and non-apomictic female parents of citrus, and using embryo rescue and in vitro culture techniques, achieved a $92 \%$ rate of triploid plants.

Esen and Soost (1971, 1973a, 1973b) concluded that triploid plants are formed from small seeds, which can be obtained via $2 \mathrm{x} \times 2 \mathrm{x}$ crosses, but the frequency of this event is generally low. In this context, the authors proposed the hypothesis that embryos formed from polyploid endosperm was the factor responsible for the small seed size, because all the seeds containing triploid embryos presented pentaploid endosperm.

In citrus, the endosperm of seeds that contain diploid embryos is naturally triploid. However, histological studies performed by Esen and Soost (1971, 1973a) demonstrated that small seeds contain embryos with pentaploid endosperm, which grows more slowly and develops prematurely, indicating that this is the factor responsible for reducing the size of the seeds that contain triploid embryos.

Cytogenetic analysis carried out by Aleza, Cuenca, Hernández, Juárez, Navarro, and Ollitrault (2015) revealed that triploid citrus embryos are associated with pentaploid endosperm, and there is strong evidence that these embryos result from fertilization of unreduced ovules by normal haploid pollen. Finally, they observed that depending on the genotype, the frequency of duplication between female gametes varied from less than $1 \%$ to more than $20 \%$.

Aleza, Juárez, Cuenca, and Ollitrault, (2012a), working with 2x $\times 4 x$ hybridizations of citrus, obtained 1061 plants from normal seeds, of which 279 were triploids (26\%), and found that in hybridizations using diploid (2n) female parents with tetraploid (4n) male parents, it is possible to obtain triploid plants from both normal and underdeveloped seeds.

In the case of $2 \mathrm{x} \times 2 \mathrm{x}$ hybridizations, triploid hybrids are obtained from the union of the $2 \mathrm{n}$ megagamophyte with haploid pollen (Esen \& Soost, 1971; Esen \& Soost, 1973a; Geraci, Esen, \& Soost, 1975). Luro, Costantino, Terol, Argout, Allario, Wincker, Talon, Ollitrault, and Morillon (2008) proposed that the restitution of the second meiotic division is the control mechanism for development of the diploid megagamophyte in the 'Clementina' variety, while Chen, Lyon, O'malley, Federici, Gmitter, Grosser, Chaparro, Roose, and Gmitter (2008) proposed that the mechanism is restitution of the first meiotic division in sweet oranges.

Some studies have shown that the aspects of the male parent and environmental conditions influence the production of triploid citrus plants (Aleza et al., 2010b; Luro et al., 2004; Viloria \& Grosser, 2005). The influence of environmental conditions on plants' reproductive success is well documented, by affecting the production and size of pollen and the growth of the pollen tube (Young \& Stanton 1990). Besides this, the temperature during the progamic phase is one of the most important environmental factors that affect the performance of pollen. However, the response to temperature during the reproductive phase depends on the genotype (Hedhly, Hormaza, \& Herrero, 2005).

Aleza, Froelicher, Schwarz, Agusti, Hernández, Juárez, Luro, Morillon, Navarro, and Ollitrault (2011), Hussain, Curk, Ollitrault, Morillon, and Luro (2011), Otto and Whitton (2000), and Saleh, Allario, Dambier, Ollitrault, and Morillon (2008) all have proposed the hypothesis that different environmental conditions, such as temperature, can have an effect on chromosome duplication events. Barrett and Hutchison (1978) identified 
polyploidy rates of $0.75 \%$ and $0.90 \%$ from seeds of citrus plants grown in Florida and California, respectively, and associated this difference with temperature variation. The effect of low temperature on polyploidization events appears to be a general rule, both in plants and animals (Otto \& Whitton, 2000; Ramsey \& Schemske, 1998). Besides the adaptive advantage of polyploids, the larger rate of polyploidization events in a colder climate could be one of the factors related to the increased frequency of polyploid species in the Northern Hemisphere (Asker \& Jerling, 1992).

Aleza et al. (2011) reported that the overall frequency of tetraploid seedlings among 30 Citrus varieties cultivated in Valencia (Spain) and Corsica (France) was from 1\% to $8 \%$ (varying from $0 \%$ to $9 \%$ according to the cultivar and environmental conditions). Besides this, they confirmed the importance of the environmental conditions on the rates of tetraploids, studying the same genotype ('Carrizo' citrange) harvested in different countries. They found higher rates in the Mediterranean than in tropical areas and significant negative correlations between the rates of tetraploids and mean temperatures during the floral induction and flowering period. Based on this, they suggested that colder growing conditions favor tetraploidization events in citrus nucellar cells.

Temperature affects the efficiency of producing citrus hybrids based on $2 \mathrm{x} \times 4 \mathrm{x}$ hybridizations. The production of triploid hybrids is influenced by the fecundation success of the pollen, which is dependent on the pollen quality. In turn, this is determined not only by the male genotype, but also the environmental conditions, level of compatibility between the male and female parents, and environmental effects on the germination and growth of the pollen tube (Viloria \& Grosser, 2005; Young \& Stanton, 1990).

Aleza et al. (2012b) studied the effect of parents and environmental conditions on the production of citrus triploid hybrids in $4 \mathrm{x} \times 2 \mathrm{x}$ sexual hybridizations during five years. The hybridization results indicated the existence of an interaction between male parents and environmental conditions on the production of triploids. Besides this, the results of two previous studies indicated that environmental conditions also affect the production of triploid hybrids in $2 \mathrm{x} \times 2 \mathrm{x}$ hybridizations (Aleza et al., 2010b; Luro et al., 2004).

Aleza et al. (2010b), investigating hybridizations using $2 \mathrm{x} \times 2 \mathrm{x}$ crosses over a period of 10 years (1996 to 2006), observed that triploid hybrids were produced by seeds that had between $52 \%$ and $62 \%$ of the size of normal seeds, and that embryo rescue and flow cytometry are two essential techniques for genetic improvement programs aiming to obtain triploids in citrus plants based on hybridizations between diploid parents.

\section{Conclusions}

The frequency of obtaining triploids varied according to the genotype (the Ortanique variety showed the greatest potential to produce triploids); of seed size (small and underdeveloped seeds presented ability to generate triploids); and the environment (triploids were obtained only in the Mucugê environment).

However, further studies must be done, to better understand the effect of environmental conditions on the formation of triploid individuals.

\section{Acknowledgements}

To the Coordination of Improvement of Higher Education Personnel (CAPES) for the granting of a master's degree scholarship to the first author, the Embrapa Cassava \& Tropical Fruits and to the National Council for Scientific and Technological Development (CNPq) for the financial assistance.

\section{References}

Aleza, P., Cuenca, J., Hernández, M., Juárez, J., Navarro, L., \& Ollitrault, P. (2015). Genetic mapping of centromeres in the nine Citrus clementina chromosomes using half-tetrad analysis and recombination patterns in unreduced and haploid gametes. BMC Plant Biology, 15, 80. https://doi.org/10.1186/ s12870-015-0464-y

Aleza, P., Cuenca, J., Juárez, J., Pina, J. A., \& Navarro, L. (2010a). 'Garbí' mandarin: A new late-maturing triploid hybrid. Horticultural Science, 45(39), 141. https://doi.org/10.21273/HORTSCI.45.1.139

Aleza, P., Froelicher, Y., Schwarz, S., Agusti, M., Hernández, M., Juárez, J., ... Ollitrault, P. (2011). Tetraploidization events by chromosome doubling of nucellar cells are frequent in apomictic citrus and are dependent on genotype and environment. Annals of Botany, 108, 37-50. https://doi.org/10.1093/aob/mcr099

Aleza, P., Juárez, J., Cuenca, J., \& Ollitrault, P. (2012a). Extensive citrus triploid hybrid production by $2 \mathrm{x} \times 4 \mathrm{x}$ sexual hybridizations and parent-effect on the length of the juvenile phase. Plant Cell Reports, 3 , 1723-1735. https://doi.org/10.1007/s00299-012-1286-0 
Aleza, P., Juárez, J., Cuenca, J., Ollitrault, P., \& Navarro, L. (2010b). Recovery of citrus triploid hybrids by embryo rescue and flow cytometry from $2 \mathrm{x} \times 2 \mathrm{x}$ sexual hybridisation and its application to extensive breeding programs. Plant Cell Reports, 29, 1023-1034. https://doi.org/10.1007/s00299-010-0888-7

Aleza, P., Juárez, J., Hernández, M., Ollitrault, P., \& Navarro, L. (2012b). Implementation of extensive citrus triploid breeding programs based on $4 \mathrm{x} \times 2 \mathrm{x}$ sexual hybridization. Tree Genetics and Genomes, 8, 1293-1306. https://doi.org/10.1007/s11295-012-0515-6

Asker, S., \& Jerling, L. (1992). Apomixis in plants. Boca Raton, FL: CRC Press.

Barrett, H. C., \& Hutchison, D. J. (1978). Spontaneous tetraploidy in apomictic seedlings of Citrus. Economic Botany, 32, 27-45. https://doi.org/10.1007/BF02906727

Cameron, J. W., \& Frost, H. B. (1968). Genetics, breeding and nucellar embriony. In W. Reuther, L. D. Batchelor, \& H. J. Webber (Eds.), The Citrus Industry (Vol. 2, pp. 325-370.). University of California Press, Berkeley.

Chen, C., Lyon, M. T., O’malley, D., Federici, C. T., Gmitter, J., Grosser, J. W., Chaparro, J. X., Roose, M. L., \& Gmitter, F. G. (2008). Origin and frequency of $2 \mathrm{n}$ gametes in Citrus sinensis $\times$ Poncirus trifoliata and their reciprocal crosses. Plant Science, 174, 1-8. https://doi.org/10.1016/j.plantsci.2007.08.005

Dolezel, J., \& Bartos, J. (2005). Plant DNA flow cytometry and estimation of nuclear genome size. Annals of Botany, 95, 99-110. https://doi.org/10.1093/aob/mci005

Dolezel, J., Greilhuber, J., \& Suda, J. (2007). Estimation of nuclear DNA content in plants using flow cytometry. Nature Protocols, 2, 2233-2244. https://doi.org/10.1038/nprot.2007.310

Esen, A., \& Soost, R. K. (1971). Unexpected triploids in Citrus: their origin, identification and possible use. Journal of Heredity, 62, 329-333. https://doi.org/10.1093/oxfordjournals.jhered.a108186

Esen, A., \& Soost, R. K. (1973a). Precocious Development and Germination of Spontaneous Triploid Seeds in Citrus. Journal of Heredity, 64, 147-154. https://doi.org/10.1093/oxfordjournals.jhered.a108373

Esen, A., \& Soost, R. K. (1973b) Seed Development in Citrus with Special Reference to $2 \mathrm{x} \times 4 \mathrm{x}$ Crosses. American Journal of Bioethics, 60, 448-462. https://doi.org/10.1002/j.1537-2197.1973.tb05945.x

Geraci, G., Esen, A., \& Soost, R. K. (1975). Triploid progenies from 2x $\times 2 x$ crosses of Citrus cultivars. Journal of Heredity, 66, 177-178. https://doi.org/10.1093/oxfordjournals.jhered.a108607

Hedhly, A., Hormaza, J. L., \& Herrero, M. (2005). Influence of genotype temperature interaction on pollen performe. Journal of Evolutionary, Biology, 18, 1494-1502. https://doi.org/10.1111/j.1420-9101.2005. 00939.x

Hussain, S., Curk. F., Ollitrault, P., Morillon, R., \& Luro, F. (2011). Facultative apomixes and chromosome doubling are sources of heterogeneity in citrus rootstock trials: Impact on clementine production and breeding selection. Scientia Horticulturae, 130, 815-819. https://doi.org/10.1016/j.scientia.2011.09.009

Knudsen, M. T., Almeida, G. F de, Langer, V., Abreu, L. S. de, \& Halberg, N. (2011). Environmental assessment of organic juice imported to denmark: A case study on oranges (Citrus sinensis) from Brazil. Organic Agriculture, 1, 167-185. https://doi.org/10.1007/s13165-011-0014-3

Latado, R. R., Yaly, M. C., Carvalho, C. R. de, \& Machado, M. A. (2007). Citrus autotetraploid plants obtained by in vitro treatment with colchicine. Pesquisa Agropecuária Brasileira, 42, 1429-1435. https://doi.org/ 10.1590/S0100-204X2007001000009

Lloyd, G., \& McCown, B. (1980). Use of microculture for production and improvement of Rhododendron spp. Horticultural Science, 15, 416-417.

Luro, F., Costantino, G., Terol, J. F., Argout, X., Allario, T., Wincker, P., .. Morillon, R. (2008). Transferability of the EST-SSRs developed on Nules clementine (Citrus clementina Hort ex Tan) to other Citrus species and their effectiveness for genetic mapping. BMC Genomics, 9, 1-13. https://doi.org/10.1186/14712164-9-287

Luro, F., Maddy, F., Jacquemond, C., Froelicher, Y., Morillon, R., Rist, D., \& Ollitrault, P. (2004). Identification and evaluation of diplogyny in clementine (Citrus clementina) for use in breeding. Acta Horticulturae, 663, 841-847. https://doi.org/10.17660/ActaHortic.2004.663.152

Ollitrault, P., Dambier, D., Luro, F., \& Froelicher, Y. (2008). Ploidy manipulation for breeding seedless triploid citrus. Plant Breeding Reviews, 20, 323-354. https://doi.org/10.1002/9780470380130.ch7 
Otto, S. P., \& Whitton, J. (2000). Polyploid incidence and evolution. Annual Review of Genetics, 34, $401-437$. https://doi.org/10.1146/annurev.genet.34.1.401

Ramsey, J., \& Schemske, D. W. (1998). Pathways, mechanisms, and rates of polyploid formation in flowering plants. Annual Review of Ecology and Systematics, 29, 467-501. https://doi.org/10.1146/annurev.ecolsys. 29.1.467

Saleh, B., Allario, T., Dambier, D., Ollitrault, P., \& Morillon, R. (2008). Tetraploid citrus rootstocks are more tolerant to salt stress than diploid. Comptes Rendus Biologies, 331, 703-710. https://doi.org/10.1016/ j.crvi.2008.06.007

Silva, S. R. da., Bezerra, D. N. F., Bassan, M. M., Avilés, T. C., \& Arthur, V. (2016). Postharvest of irradiated tahiti lime fruits. Revista Brasileira de Fruticultura, 38, 272. https://doi.org/10.1590/0100-29452016272

Syvertsen, J. P., \& Sanchez, F. G. (2014). Multiple abiotic stresses occurring with salinity stress in citrus. Environmental and Experimental Botany, 103, 128-137. https://doi.org/10.1016/j.envexpbot.2013.09.015

Viloria, Z., \& Grosser, J. W. (2005). Acid citrus fruit improvement via interploid hybridization using allotetraploid somatic hybrid and autotetraploid breeding parents. Horticultural Science, 130, $392-402$. https://doi.org/10.21273/JASHS.130.3.392

Young, H. J., \& Stanton, M. L. (1990). Influence of environmental quality on pollen competitive ability in wild radish. Science, 248, 1631-1633. https://doi.org/10.1126/science.248.4963.1631

\section{Copyrights}

Copyright for this article is retained by the author(s), with first publication rights granted to the journal.

This is an open-access article distributed under the terms and conditions of the Creative Commons Attribution license (http://creativecommons.org/licenses/by/4.0/). 